\title{
Peningkatan Prestasi Belajar Mata Pelajaran IPA melalui Model Pembelajaran Think Pair Share
}

\author{
Yulistyorini $^{(1)}$ \\ ${ }^{1}$ Guru SDN 1 Ngadirejo Pogalan Trenggalek \\ Email: 1yulistyorini@gmail.com \\ DOI:http://doi.org/10.28926/riset_konseptual.v2i4.107
}

\begin{abstract}
ABSTRAK
Penelitian ini bertujuan untuk memperoleh gambaran yang objektif mengenai peningkatan prestasi belajar mata pelajaran IPA melalui model pembelajaran Think Pair Share bagi siswa kelas II semester I tahun pelajaran 2016/2017 di SDN 1 Ngadirenggo, Kecamatan Pogalan, Kabupaten Trenggalek. Penelitian dilakukan di SDN 1 Ngadirenggo, Kecamatan Pogalan, Kabupaten Trenggalek. Subjek dalam penelitian ini adalah seluruh siswa kelas II semester I tahun pelajaran 2016/2017 di SDN 1 Ngadirenggo, Kecamatan Pogalan Kabupaten Trenggalek yang berjumlah 18 siswa, dengan rincian 8 siswa perempuan dan 10 siswa laki-laki. Hasil akhir penelitian didapatkan siswa tuntas pada siklus I mencapai 15 siswa (83\%), sedangkan pada siklus II mencapai 17 siswa (94\%), terjadi peningkatan ketuntasan belajar sebesar $11 \%$ atau sebanyak 2 dari 18 siswa
\end{abstract}

Kata kunci: Prestasi belajar, IPA, Think Pair Share

\section{PENDAHULUAN}

Kemampuan guru menyampaikan materi merupakan salah satu faktor yang dapat menentukan tingkat keberhasilan siswa dalam belajar. Pada faktor ini ada beberapa hal yang perlu dipahami oleh guru, misalmya metode atau model mengajar yang dipergunakan, media yang dipergunakan, serta kemampuan-kemampuan lain seperti kemampuan memberikan pertanyaan, kemampuan mengelola kelas, dan masih banyak lagi yang lain. Apabila kemampuan guru dalam hal tersebut lebih positif, maka tingkat keberhasilan siswa juga lebih tinggi. Belajar adalah suatu proses perubahan di dalam diri manusia. Apabila setelah belajar tidak terjadi perubahan dalam diri manusia, maka tidaklah dapat dikatakan bahwa padanya telah berlangsung proses belajar. Pengertian belajar menurut ahli pendidikan modern adalah suatu bentuk pertumbuhan atau perubahan dalam diri seseorang yang dinyatakan dalam cara-cara bertingkahlaku yang baru berkat pengalaman dan latihan. Tingkah laku yang baru itu misalnya dari tidak tahu menjadi tahu, timbulnya pengertian baru, serta timbul dan berkembangnya sifat-sifat sosial, susila, dan emosional. Belajar dimaknai sebagai bentuk pertumbuhan atau perubahan dalam diri seseorang yang dinyatakan dalam cara-cara bertingkah laku. Mata pelajaran IImu Pengetahuan Alam (IPA) selain mempunyai fungsi di atas, juga mempunyai tujuan menanamkan pengetahuan dan konsep-konsep IImu Pengetahuan Alam (IPA) yang bermanfaat dalam kehidupan sehari-hari, menanamkan rasa ingin tahu dan sikap positif terhadap Ilmu Pengetahuan Alam (IPA) dan teknologi, mengembangkan ketrampilan proses untuk menyelidiki alam sekitar, memecahkan masalah dan membuat keputusan, ikut serta dalam memelihara, menjaga dan melestarikan lingkungan alam, mengembangkan kesadaran tentang adanya hubungan yang saling mempengaruhi antara Ilmu Pengetahuan Alam (IPA), lingkungan, teknologi dan masyarakat, dan menghargai alam dan segala keteraturannya sebagai salah satu ciptaan Tuhan. Think Pair Share suatu model pembelajaran kooperatif yang memberi siswa waktu untuk berfikir dan merespon serta saling bantu satu sama lain. Model pembelajaran ini merupakan model pembelajaran kooperatif dilakukan dengan adanya kerjasama antar siswa. Kelebihan dari model pembelajaran Think Pair Share adalah mudah diterapkan di berbagai jenjang pendidikan dan dalam setiap kesempatan, menyediakan waktu berfikir untuk meningkatkan kualitas siswa, siswa lebih aktif berfikir 
JURNAL PENDIDIKAN: Riset dan Konseptual, Vol. 3 No. 1, January 2019 www.journal.unublitar.ac.id/ip

E-ISSN: 2598-2877

P-ISSN: 2598-5175

mengenai konsep dalam mata pelajaran, siswa lebih memahami konsep topik pelajaran selama diskusi, siswa dapat belajar dari siswa lain, setiap siswa dalam kelompoknya mempunyai kesempatan untuk berbagi atau menyampaikan idenya.

Berdasarkan pada hasil observasi peneliti yang dilakukan pada semester I tahun pelajaran 2016/2017, selama 2,5 bulan. Penelitian dilakukan dengan 2 siklus, dan masing-masing siklus sebanyak 2 pertemuan pada bulan sepetember-November 2016. Berpijak pada kajian dari tujuan yang ingin dicapai guru SDN 1 Ngadirenggo Kecamatan Pogalan Kabupaten Trenggalek yakni meningkatkan kualitas pembelajaran di kelas terutama peningkatan prestasi belajar mata pelajaran IPA siswa kelas II semester I. Melalui penelitian ini peneliti berharap memperoleh gambaran yang objektif mengenai peningkatan prestasi belajar mata pelajaran IPA melalui model pembelajaran Think Pair Share bagi siswa kelas II semester I sehingga dapat dipergunakan sebagai feed back oleh guru untuk melakukan kegiatan pembelajaran berikutnya. Selanjutnya sekolah dapat memberikan motivasi pengembangan model pembelajaran dalam usaha meningkatnya prestasi belajar siswa serta meningkatnya kemampuann guru dalam mengajar, dan berimplikasi pada kualitas sekolah dapat meningkat dan dapat meningkatkan kepercayaan masyarakat.

\section{METODE}

Penelitian menggunakan Penelitian Tindakan Kelas (PTK) dengan 4 tahapan yaitu tahap perencanaan, tahap tindakan, tahap observasi, dan tahap refleksi. Penelitian dilakukan pada semester I tahun pelajaran 2016/2017, selama 2,5 bulan dengan 2 siklus, dan masing-masing siklus sebanyak 2 pertemuan pada bulan sepetember-November 2016, subjek berjumlah 18 siswa, dengan rincian 8 siswa perempuan dan 10 siswa laki-laki. Penelitian dilakukan di SDN 1 Ngadirenggo Kecamatan Pogalan Kabupaten Trenggalek. Instrument mempergunakan soal tes dengan 10 soal pilihan ganda.

Teknik pengumpulan data yang digunakan berupa observasi, wawancara, dan dokumentasi berupa hasil tes. Data dianalisis dengan menggunakan metode analisis data statistik. Data-data yang dianalisis berupa data prestasi belajar siswa (hasil nilai tes akhir siswa), nilai rata-rata kelas, prosentase ketuntasan, modus/nilai yang sering muncul, dan data peningkatan prestasi belajar, dengan cara mencari selisih antara hasil dari Siklus I dengan hasil pada siklus II.

HASIL

Penelitian dilakukan melalui tahapan pra siklus, siklus I dan Siklus II. Tahap pra siklus proses melalui perencanaan, pelaksanaan, dan refleksi dilaksanakan pada hari sabtu tanggal, 03 september 2016. Materi pra siklus memasang KKM sebesar 70. Dari 18 siswa terdapat 2 siswa (11\%) mencapai kualifikasi istimewa, 3 siswa (17\%) mencapai kualifikasi sangat baik, 5 siswa (28\%) mencapai klasifikasi baik, 3 siswa $(17 \%)$ mencapai kualifikasi cukup, 4 siswa (22\%) mencapai kualifikasi kurang, 1 siswa (6\%) mencapai kualifikasi sangat kurang. Dengan demikian terdapat 13 siswa $(72 \%$ siswa) tuntas dan 5 siswa ( $25 \%$ siswa) tidak tuntas. Nilai yang sering muncul (modus) berada pada nilai 80 atau berada pada kualifikasi lebih dari cukup yakni sebanyak 5 siswa (28\%). Nilai rata-rata kelas pada pra siklus adalah 76 . Refleksi diketahui masih menggunakan metode ceramah, tanpa media, buku paket, LKS, tanpa media pembelajaran kurang menarik siswa.

Pada siklus 1 proses pembelajaran menyiapkan silabus, RPP, LKS, Media/Sumber Belajar, daftar hadir siswa yang keseluruhan disesuaikan dengan model TPS. Hasil data dinyatakan dari subjek 18 siswa terdapat 4 siswa (22\%) mencapai kualifikasi istimewa, 3 siswa (17\%) mencapai kualifikasi sangat baik, 5 siswa (28\%) mencapai kualifikasi baik dan 3 siswa (17\%) mencapai kualifikasi cukup, 2 siswa $(11 \%)$ mencapai kualifikasi kurang, 1 siswa (6\%) mencapai kualifikasi sangat kurang. Dengan demikian maka terdapat 15 (83\%) siswa tuntas dan $3(17 \%)$ siswa tidak tuntas. Nilai yang sering muncul (modus) berada pada nilai 80 atau berada pada kualifikasi baik yakni sebanyak 5 siswa (28\%), nilai rata-rata kelas pada siklus I adalah 81 . Refleksi 
JURNAL PENDIDIKAN: Riset dan Konseptual,

Vol. 3 No. 1, January 2019 www.journal.unublitar.ac.id/ip

E-ISSN: 2598-2877

P-ISSN: 2598-5175

yang di dapat model pembelajaran Think Pair Share (TPS), terlihat dapat meningkatkan semangat belajar anak, walaupun anak masih terlihat canggung dan ragu-ragu, perlu menambah sumber belajar, perlu pengacakan siswa sesuai kemampuan.

Pada siklus 2 dengan mengkaji hasil siklus 1 didapatkan siswa yang dapat mencapai tuntas 17 siswa (94\%) dengan criteria 4 siswa $(22 \%)$ dengan kualifikasi istimewa; 6 siswa (33\%) kualifikasi amat baik; 3 siswa (17\%) mencapai kualifikasi baik; 4 siswa (22\%) mencapai kualifikasi cukup dan sebanyak 1 siswa (6\%) mencapai kualifikasi kurang. Dengan demikian maka terdapat 17 (94\%) siswa tuntas dan $1(6 \%)$ siswa tidak tuntas. Nilai modus berada pada nilai 90 atau berada pada kualifikasi sangat baik yakni sebanyak 6 siswa (33\%), nilai rata-rata kelas pada siklus II adalah 84. Refleksi yang didapat bahwa tingkat keaktifan siswa sudah mencapai $90 \%$, nilai rata-rata siswa sudah menunjukkan peningkatan yang sangat signifikan, dan siswa sudah dapat mencapai ketuntasan $94 \%$.

\section{PEMBAHASAN \\ Perbandingan Hasil Belajar Siswa pada Siklus I dan Siklus II}

Perbandingan hasil penelitian dari siklus 1 ke siklus 2 yang terkaji melalui model pembelajaran Think Pair Share (TPS) adalah siswa tuntas pada siklus I mencapai 15 siswa (83\%), sedangkan pada siklus II mencapai 17 siswa (94\%). Dengan demikian ada kenaikan tingkat ketuntasan belajar sebesar $11 \%$ atau sebanyak 2 dari 18 siswa. Nilai rata-rata kelas yang dicapai siswa pada siklus I sebesar 81. Sedangkan pada siklus II naik menjadi 84. Dengan demikian nilai rata-rata kelas naik sebesar 3 poin. Data perbandingan menunjukkan terjadinya peningkatan prestasi belajar siswa dari siklus 1 ke siklus 2 yang meliputi (1) peningkatan prosentase ketuntasan belajar dari $83 \%$ menjadi 94\%, (2) dan peningkatan nilai rata-rata kelas dari 81 menjadi 84. Berdasarkan hasil tersebut, maka hasil uji hipotesis dapat disampaikan bahwa terjadi peningkatan prestasi belajar mata pelajaran IPA melalui model pembelajaran Think Pair Share bagi siswa kelas II semester I Tahun Pelajaran 2016/2017 di SDN 1 Ngadirenggo Kecamatan Pogalan Kabupaten Trenggalek.

\section{KESIMPULAN}

Pelaksanaan penelitian tindakan kelas dengan model pembelajaran Think Pair Share dapat meningkatkan prestasi belajar mata pelajaran IPA siswa kelas II semester 1 Tahun Pelajaran 2016/2017 SDN 1 Ngadirenggo Kecamatan Pogalan Kabupaten Trenggalek. Hal ini terbukti berdasarkan data kajian yang berupa data yang dapat dipergunakan sebagai pedoman dalam mengambil kesimpulan. Data perbandingan yang membuktikan adanya peningkatan prestasi belajar siswa dari siklus I ke siklus II yang meliputi peningkatan prosentase ketuntasan belajar dari $83 \%$ menjadi $94 \%$ dan peningkatan nilai rata-rata kelas dari 81 menjadi 84

\section{SARAN}

Diharapkan agar guru dapat meningkatkan semangat diri untuk selalu melakukan inovasi, bersifat kreatif, dan mau mengembangkan dirinya agar dapat tercapai kemajuan pendidikan khususnya di lembaga pendidikan tempat bertugas. Adanya inovasi yang dilakukan oleh guru tentunya juga dapat menghasilkan output yang semakin meningkat, karena siswa yang belajar dengan semangat dan tidak dihantui oleh rasa bosan akan dapat mengembangkan dirinya dengan maksimal. 
JURNAL PENDIDIKAN: Riset dan Konseptual, Vol. 3 No. 1, January 2019 www.journal.unublitar.ac.id/ip E-ISSN: 2598-2877

P-ISSN: 2598-5175

\section{DAFTAR RUJUKAN}

Aqib, Zainal. 2012. Profesionalisme Guru dalam Pembelajaran. Surabaya: Insan Cendekia

Arikunto, Suharsimi. 2006. Penelitian Tindakan Kelas. Jakarta. BumiAksara

Arikunto, Suharsimi. 2009. Prosedur Penelitian Suatu Pendekatan Praktek. Jakarta:

Rineka Cipta

Djamarah, Syaiful Bahri.2011. Psikologi Belajar: Jakarta: Rineka Cipta

Fajri, Em Zul. 2008. Kamus Lengkap Bahasa Indonesia. Diffa Publisher

Shoimin, Aris. 2008. 68 Model Pembelajaran Inovatif dalam Kurikulum 2013.Yogyakarta: Ar-Ruzz Media.

Susilo.2007 Manajemen Penelitian Tindakan Kelas. Surabaya: Insan Cendekia. 